\title{
PECULIARITIES OF THE POLICE OFFICER'S PROFESSION IMAGE IN THEIR ATTITUDE
}

Rasa Dobrzinskiene Mykolas Romeris University, Lithuania E-mail: rasa.dobrzinskiene@mruni.eu

\section{Giedre Pauriene Mykolas Romeris University, Lithuania E-mail: pauriene@mruni.eu}

Iryna Kushnir Fedkovych Chernivtsi National University, Ukraine E-mail: i.kushnir@chnu.edu.ua

Dimitri Grytsyshen Zhytomyr Polytechnic State University, Ukraine E-mail: gritsishen-do@mail.ru

Kostiantyn Malyshev Zhytomyr Polytechnic State University, Ukraine E-mail:malyshev.kostiantyn@tutanota.com

Submission: 8/8/2021

Revision: 9/13/2021 Accept: 9/26/2021

\section{ABSTRACT}

Aspects of choosing a profession and career planning are closely related to the description of the features of the image of the profession, otherwise known as the image of the profession. The choice of profession is an essential part of life, which has a significant influence upon the person and their further occupation. Furthermore, the choice of profession and job is related to the satisfaction of financial, social and personal needs. Therefore, it is very important that the choice of profession is as accurate as possible and that the profession evokes a strong feeling of vocation. A career develops accordingly, if a person is satisfied with the job and one's current expectations meet the current situation, then the career development is successful and thrives as individually sought. For a career to follow a successful developing process it is vital to meticulously systematize the characteristics of a particular profession that would help to decide whether 
one wants to choose it not. Due to these reasons whilst researching the police officer's image it is crucial to assess the point of view of current police officers in regard to the officer's image. Correspondingly, the purpose of the article is evoked - to reveal the perception of police officers of the image of their profession. To achieve it, the concept of choosing a profession is discussed, emphasizing the importance of vocation and the path of professional development - career; the change in the attitude of police officers about the image of their profession and its factors are determined. The hypotheses are confirmed disparately. After an empirical study, the first hypothesis - the average of the respondents' assessment of the current attitude towards the characteristics of the police officer profession is statistically significantly different from the attitude before choosing this profession - was confirmed. The second hypothesis was only partly confirmed. It was revealed that the average assessment of the characteristics of the police profession for both men and women decreases depending on the degree of the police officer.

Keywords: police officer; profession's image; choice of profession; profession's characteristics; factors contributing in the choice of profession

\section{INTRODUCTION}

Choosing a profession is a challenge for many young people. Despite all the doubts and the difficulties of choosing a profession, many young people choose one or another further career path. The process of learning and acquiring a certain profession is determined by the social and psychological needs of the personality.

After all, work is always associated with the essential satisfaction of human and social needs, it is like one's duty, necessity, condition of well-being, part of an individual biography. Though, it is vital to find a profession that you truly like, to find a proper and enjoyable job environment, and to determine the place of your professional activity in your life.

Scientists conducting research in a field of factors leading to a professions choice have noticed that these factors are related with one's age, gender, general and special abilities, professional interests, professional experience or degree, and their parents' education level. (Beresnevičienè, 2003).

Often professions are chosen by imitating already familiar professions that are visible or encountered in life. Besides, socio-economic factors also play a major role (Benesch, 
DOI: 10.14807/ijmp.v12i6.1756

2002). It is critical, whether the choice of profession is successful because the future occupation, point of view, and satisfaction in one's occupation depends on that. Furthermore, all this determines their work productivity and their desire to plan a career, which is often a certain goal of the employee, viz. a driving force for self-realization in the workplace.

Youth choses police officer's profession for various reasons: some are interested in the activity itself; others are often attracted by external non-essential characteristics of the profession (attractive working conditions or environment, beautiful clothes, elements of romance) or the attractiveness of the educational institution (Braendle \& Grundmann, 2020).

Accordingly, a research has been conducted, which seeks to find out what is the current formed police officer's image in Lithuania from the Lithuanian police officers' point of view. They can present their assessments in relation to factors of choosing a profession and pursuing a career, and assess their current positions accordingly. Profession's image is a list of profession's characteristics, which helps to reveal the specifics of the profession and characteristics applicable to a certain profession. Therefore, the image creation of the profession of police officers and its evaluation through the eyes of police officers themselves is an important aspect in the analysis of the characteristics of the profession.

Research object - police officer’s profession's image.

Research methods - theoretical: analysis and synthesis of scientific literature, logical and analytical methods for the analyses of the main problems related to the choice of profession and future career. The summarization method provided an opportunity to refine the most important results and thoughts. The questionnaire method was used to collect data from the empirical quantitative study; Such parametric analysis methods were used for data analysis using SPSS program: paired student-t test and multiple linear regression, which is applied in order to reveal the dependence of the investigated phenomenon on several other independent variables.

\section{Hypotheses:}

1. The average of the respondents' assessment of the current attitude towards the characteristics of the police officer profession differs statistically significantly from the attitude before choosing this profession.

2. The assessment of the characteristics of the profession depends statistically significantly on the official's length of service, age and the police rank.

Article's purpose - to reveal police officers' perception of their professional image. 
To achieve this, the following tasks are set:

1. To discuss the concept of choosing a profession, emphasizing the importance of vocation and the path of professional development - career.

2. To determine the change in the attitude of police officers to the picture of their profession and its factors.

\section{LITERATURE REVIEW}

\subsection{The choice of profession}

The choice of profession - the most important choice, which determines the rest of a young person's life. However, according to some scientists, the choice of profession is a multiple act and long-term process (Jovaiša, 2001).

Studies have shown that most people change professions at least twice in their lives. The choice of occupation depends on the socio-economic situation, which includes three interrelated and overlapping variables: economic situation, which is determined by income; social status dependent on education; employment status assessed by profession. Most people define their position and significance in society according to their profession, so selfawareness as well as self-esteem depend on it.

A profession reflects not only individual job functions or skills, but also a lifestyle and environment (McMahon \& Patton, 2018).

A profession is a combination of human activities based on relevant knowledge, skills, abilities and skills, which provides a precondition for satisfaction, material provision and active participation in the structures of public life (Laužackas, 2005).

Perception of the meaning of work depends both on the characteristics of the person and on the nature of the work itself. Work can satisfy various needs: financial, social, personal, because the profession defines a person's position in society, his value system, norms of behavior, life aspirations, etc.

Work is defined as "a positive, work-related state of mind characterized by drive, dedication, and assimilation” (Schaufeli et al., 2002).

The problem of choosing a profession has been constantly researched from a long time ago. Plato in one of his most notorious literature pieces "Republic" discussed the natural differences between people, which determine the nature of their professional activity. 
Today, various theories are used to solve the problem of choosing a profession: development, self-awareness (Super, 1990), typologies (McMahon \& Patton, 2018), social learning (Mitchell \& Krumboltz, 1990), professional aspirations (Gottfredson, 1981), adaptation to work (Swanson \& Schneider, 2020).

Nowadays, these theories are combined into a single theory of convergence, even though their diversity is being advocated (Jovaiša, 2001). The choice of profession is determined by the interplay of many variables. Some of them include the characteristics of the individual, and some include the environment features.

According to Augienès (2018), the choice of one's profession is influenced by one's personality and its traits; intelligence; skills; health; innate physical characteristics; gender; values; provisions (based on a system of values); interest; propensity (internal personality need for a particular activity); familiarity with oneself (perceiving your own image); needs (first reference source for choosing a profession); motives (incentives for professional activity). The environment: family, school, friends, and living environment may be factors of environmental influence.

An equally important factor influencing professional choice is the professional vocation, which expresses a person's experiences arising from contact with a certain activity and based on internal attitudes (Laužackas, 2005).

Professional vocation is closely related to professional self-determination. If the vocation is felt for a certain profession, then the situation of professional self-determination is resolved easier and faster, because the young person decides whether or not to choose a profession, relying on his or her vocation. Inevitably, various internal and external factors also act at that time.

The choice of professional activity is correct only when the subjective value of the pursued profession is reconciled with objective personal powers (Pukelis, 2007).

To work according to the vocation is a real blessing, because the work is easy and good, the greatest stress does not cause fatigue, the fruits of work are great, your colleagues enjoy you and you always feel their sincere support for your achievements. (Jovaiša, 2001). If the choice of profession is determined not by internal but by external factors (honor, income), then a person usually has to force himself to work exclusively by willpower. A professional vocation is an integral part of a broader and more comprehensive professional orientation in terms of the relationship between a person and a profession. It is often assumed that 
INDEPENDENT JOURNAL OF MANAGEMENT \& PRODUCTION (IJM\&P)

http://www.ijmp.jor.br

v. 12, n. 6, Special Edition ISE, S\&P - November 2021

ISSN: 2236-269X

DOI: 10.14807/ijmp.v12i6.1756

professional orientation is the most important part of a professional vocation, which includes a person's motivation (professional interests, provisions, attitudes, beliefs, etc.).

Professional suitability, which includes a person's psychological and physical abilities as well as individual character traits, is seen here as another important part of a professional vocation. According to many researchers, professional vocation is formed and revealed mostly during late adolescence (Pukelis, 2008).

Different professions have different requirements. Before choosing one or another profession, it is worth considering and properly assessing the following aspects: health status, physical fitness, talents, interests and hobbies, temperament and character traits, as well as employment prospects (Braendle \& Grundmann, 2020).

One of the main elements of human self-realization is the choice of profession, and at the same time the realization of one's abilities. Everyone has the freedom and right to choose a profession, but it should be remembered that it is chosen not only because of high prestige in society, or high income, but also because of self-realization, fulfilment, disclosure of one's abilities.

\subsection{The concept of career}

Career preparation is the planning of your life by performing meaningful functions in various areas of activity. Career is closely linked to the successful choice of a profession that suits you. Career education does not always require basic education, experience or skills, as well as the personal ability to find the right job for oneself, and to be able to adapt to changing circumstances as market needs change. Having learned all this, one can successfully climb the career planning stages.

In a general sense, a career is a path of professional development, constantly setting new goals, challenges, and achieving new positive results (Greenhaus \& Callanan, 2006). In general, the concept of career is broad and diverse. A career is generally defined as a successful activity, a success in life, a type of activity.

Career consists of external (high salary, qualification) and internal (satisfaction, selfrealization) benefits. In other words, it is an individual improvement in the direction of a successfully chosen activity and a positive evaluation of it from both a personal and a social point of view. However, the concept of working career is often perceived differently by the employees themselves than in the scientific literature. A career is usually imagined as a rapid and successful rise in position. 
However, according to Wadhwa and Guthrie (2018), a career is not just a rise in position. They call a career a process that is not led by an organization but rather by an individual. Thus, such a concept of career includes an individual's experience in various fields - education, education, work activities, and so on. Therefore, a career continues throughout an individual's working life. The decision on career success is an individual one in all cases. If an individual is satisfied with his or her job, no one can claim that his or her career is unsuccessful.

Career can also be described as the development of employee positions in the company. Although a career is usually associated with vertical worker growth, it can also involve horizontal movement. As the level of employee demands rises, it is becoming increasingly important (Sakalas \& Salcius, 1997). However, a career is also called a natural rise in the ladder of service as one develops oneself (Sakalas \& Šilingienè, 2000).

It is a rapid, successful rise in service, associated with rising salary, higher status, and prestige (Mitchell \& Krumboltz, 1990). In addition, a career can also be finding a job you enjoy working on (Super, 1990).

In any case, a successful professional career is possible only when a person realises himself, when the profession meets the person's interests and hobbies (Kirkpatrick \& Mortimer, 2002).

The same as with choosing a profession, career formation is influenced by psychological and organizational factors. If an individual has made the right choice of profession, has a professional vocation, he or she has more opportunities to experience the satisfaction of pursuing a career.

Such satisfaction increases an individual's self-confidence and emerges as a motivating factor for work (Sakalas \& Salcius, 1997). In addition, it must be borne in mind that the understanding of each person's career is individual and certainly not everyone wants and aspires to occupy high management positions. Meanwhile, the task of the organization is to fully support employees seeking a career, provide the necessary information and training.

The microclimate of the organization must be such as to encourage employees to move forward, to keep moving and to strive for something new and undiscovered on a daily basis. A good climate in the work environment is even able to outweigh the desire to earn a high salary (Grecco et al., 2021). 
DOI: 10.14807/ijmp.v12i6.1756

Especially in this case, the important role is of the manager, who should accordingly support job satisfaction rather than ruin it (Samad et al. 2021).

The work environment is also important because comfort in the workplace, lighting, cleanliness increase employee job satisfaction (Le-Hoang et al., 2020), because it shows the organization's respect and concern for its employee.

However, only the employees themselves remain responsible for the ultimate success of their careers. Every young person must understand the basic attitudes: to be able to take responsibility for themselves and plan for their future; be able to use market information; to be able to react in a timely manner and to adapt flexibly to changing labor market conditions.

\subsection{Profession's characteristics description or profession's image}

Aspects of career choice and career at work are closely related to the picture of the profession, which reveals the characteristics of each profession. When analyzing specific professions as objects of educational research, it is necessary to single out as many parameters that describe them as possible. The more information is available about each of the professions studied, the more its characteristics or characteristics are collected, the more detailed the description of the characteristics of the profession is created.

By systematizing those features, it is possible to create a description of the features of the profession, also called an image of the profession. The image of the profession is used not only in comparative research of professions, classification of professions, but is especially important when conducting research of professions related to the development of professional preparation programs.

The image of a profession is made up of most of the characteristics of the profession in order to assess in more detail its compliance with the expectations of those who choose it. Accordingly, characteristic of the profession of police officers are collected, systematized, analyzed.

The German scientist Scheer (2010) along with the participants of the research formed the characteristics of the profession of a police officer and modelled the picture of this profession by identifying the measurement elements used in the research. Similarly, this article attempts to look at the picture of the profession of Lithuanian police officers. 
DOI: 10.14807/ijmp.v12i6.1756

\section{DATA AND METHODOLOGY}

\subsection{Research methodology}

For the analysis of empirical data such parametric analysis methods were in use: paired student-t test was used to compare differences in the attitudes of the same group of respondents towards the characteristics of the profession before and after its acquisition; quantitative variables (data distributed according to the regular distribution order); multiple linear regression is applied to reveal the dependence of the investigated phenomenon on several independent variables (continuous or categorical). The conduction of this analysis seeks to reveal an answer to this inquiry: Does the assessment of the characteristics of the profession depend on the police officer's length of service, age and degree?

The operationalization of the object took place in several stages:

a) The measurement elements of the study are based on German scientist C.A. Scheer's conducted research results, during which in order to prepare the police officer's profession's characteristics list, research subjects were given these questions: "How do you imagine yourself working as a police officer?", "Why would you want to become a police officer?" or "Why don't you want to become a police officer?" Phenomenologically, the different activities seem completely different and have nothing to do with each other. According to this approach, German scientist C.A. Scheer along with research participants developed ideas, and essentially formed police officer's profession's characteristics. Therefore, identifying the measurement elements used in the study. In this case, they were strolling on the path of empiricism without one definite theory. In our case, the research also may be considered empiricist because it is not based on one definite theory.

b) The next step in the operationalization of the object is a survey for a group of 28 future Lithuanian police officers, who during the internship already got acquainted with this profession in more detail. Respondents were asked to write down the characteristics of the police profession and their responses were put in comparison with the German scientist's C.A. Scheer's formed list of the profession's characteristics. Essential divergences were not present.

Later, during a discussion with police officers with more than five years of service and with a police rank of chief inspector, or higher, the lists of characteristics of the profession of police officers were compared again and the most relevant and more pivotal 
characteristics were emphasized. In comparison with the German scientist's C.A. Scheer's profession’s characteristics list these characteristics were renounced: "Professional inaction", "Competence for everything", "Mass events", "Responsibility", "Specialization".

Profession’s attributes such as "Professional inaction" and "Mass events" are indispensable for the police officers who have gone through a German law enforcement preparation because one of their functions is to be within one's control to quickly respond and arrive at the whereabouts where an unexpected incident has taken place. The police officers are in constant readiness, waiting, which they call "Professional inaction". Besides, they perform other operations: ensure order and safety during demonstrations and other events, look about for missing individuals.

Profession's attribute emphasized by Germans "Competence for everything" may be associated with the fact that in Germany a significant level of competence is expected from a police officer in all fields of social life, even in those, for which he does not hold responsibility. Germany has formed a very clear authority of a police officer in a community, however, such authority of the community in Lithuania is yet to be formed.

"Specialization" as a characteristic emphasizing the narrow content of professional activity, is not common for Lithuanian police officers. Concerning the attribute "Responsibility" there was a long elaborate discussion until a final conclusion was inferred that if we include responsibility as a profession's characteristic, then we would also be obliged to include other professional ethics principles of a police officer like respect for people and the state, justice, honesty, altruism, exemplary, etc. because responsibility is one of the named ethics principles itself. It has been decided that the research questionnaire will encompass 24 police officer's profession attributes.

The first block of questions was intended to determine how police officers comprehend and perceive their own profession's picture. This question may be put more concisely: What were the considered characteristics of this profession before choosing this profession? What are the considered characteristics of the profession right now, viz. during this research? However, it is not enough to find out from the respondents' point of view what characteristics of the profession are characteristic of the profession of a police officer. 
INDEPENDENT JOURNAL OF MANAGEMENT \& PRODUCTION (IJM\&P)

http://www.ijmp.jor.br

v. 12, n. 6, Special Edition ISE, S\&P - November 2021

ISSN: 2236-269X

DOI: 10.14807/ijmp.v12i6.1756

Table 1: 24 police officer's profession's characteristics in the research questionnaire

\begin{tabular}{|l|l|}
\hline Nr. & Research measurement element - Profession's attribute \\
\hline 1. & Patrol on foot, by car \\
\hline 2. & Respect in society \\
\hline 3. & Shift work \\
\hline 4. & Traffic supervision \\
\hline 5. & Teamwork/cooperation \\
\hline 6. & Risk, danger \\
\hline 7. & Implementation of law and order \\
\hline 8. & Action, tension \\
\hline 9. & High wages \\
\hline 10. & Taking care of the country's internal security \\
\hline 11. & Working with "special" equipment \\
\hline 12. & Office work, work with documents \\
\hline 13. & Possession of power \\
\hline 14. & Occupational safety \\
\hline 15. & Help others \\
\hline 16. & Sports \\
\hline 17. & Career opportunities \\
\hline 18. & Working with various people \\
\hline 19. & Fight against crime \\
\hline 20. & Uniform \\
\hline 21. & Absents of monotony, variety of work tasks \\
\hline 22. & Special rights \\
\hline 23. & Firearm \\
\hline 24. & Good physical and psychological preparation \\
\hline
\end{tabular}

Source: analyzed by the authors

The questionnaire is made out of several blocks.

It is also necessary to find out whether these characteristics are appealing to the respondents, and to find out whether these characteristics are not evoking any feeling of dissatisfaction in their chosen profession. Therefore, the second block of questions seeks to find an answer to these questions: What do you think of the individual's characteristics of the profession assessed on a scale from "very like" to "very dislike"? In the third block of questions respondents submitted their demographic characteristics (time of service, age, gender, police rank).

\subsection{Collected empirical data}

Since the research problem is connected with professional expectations, the subjects for the research are police officers - students, who every year during internships are directly acquainted with professional activities. Furthermore, part-time study officers with longer professional experience and, of course, graduates of our faculty working in the police throughout Lithuania were also interviewed. 
Efforts were made to distribute an approximately equal number of questionnaires among groups of respondents with different professional backgrounds in order to collect the most accurate data possible. It should be noted that the training and future study time of future police officers is included in the length of service in the internal service, but only immediately after starting the service, therefore in this study the length of service of future full-time police officers is zero, as it is not clear whether another professional path will be chosen.

The sample for this study was based on a nonprobability convenience sampling. Therefore, based on the data obtained in this study, it is possible to judge for the whole of the Republic of Lithuania, and to draw a conclusion that this is the opinion of all police officers in the Republic of Lithuania.

According to the data of the Lithuanian Department of Statistics, the number of police officers in Lithuania in 2020 was 7,849 (Crime and Law Enforcement Activities, 2020).

Thus, the sample size in order to summarize the survey results for the whole general population with a sample error of 5\% (Rupšienè, Rutkienè, 2015), based on the Paniotto formula, would be

$$
N=1 /\left(0,05^{2}+(1 / 7849)\right)=381
$$

With the direct participation of the researchers in the survey, 207 questionnaires were distributed, all of which returned, but only 202 were processed, and five questionnaires were rejected as potentially invalid. Personal acquaintances of the faculty were also contacted and asked to fill in the questionnaire by e-mail form. In this way, 168 questionnaires were received. Thus, in total of 375 officials participated in the investigation ( $\mathrm{N}=375)$.

In this research, the ethical aspects of the application of the written survey (questionnaire) method, such as voluntary participation, anonymity, were taken into account. The principles of research ethics identified by Kardelis (2017) were also followed: 1) explain to the participants where and for what purpose you will use the information obtained during the research; 2) Remember that people who have agreed to participate in the survey are doing you a favor. During the distribution of the questionnaires, the respondents were contacted and the questions were answered. Police officers were also explained why such an inquiry is being conducted and what its purpose is.

For the validity of the content of the measuring instrument, which shows whether the selected measuring elements form the whole content of the phenomenon, viz. whether the 
INDEPENDENT JOURNAL OF MANAGEMENT \& PRODUCTION (IJM\&P)

http://www.ijmp.jor.br

v. 12, n. 6, Special Edition ISE, S\&P - November 2021

ISSN: 2236-269X

DOI: 10.14807/ijmp.v12i6.1756

selected 24 characteristics of the profession cover the whole picture of the profession, several stages of operationalization were performed. Typically, the content of a research instrument is validated by experts.

In our case, this validation took place in the third phase of the operationalization of the facility with the participation of police officers with more than five years of service and with the rank of inspector or higher police ranks.

Since the measurement elements of the study are the German scientist's C.A. Scheer's results of a research to compile a list of characteristics of a police officer's profession, it is likely that the research instrument has content validity.

The validity of a construct determines whether a field described by a theoretical concept can be examined by a truly conceived study.

When specific features are assessed in the study and abstract theoretical constructs are not used, according to Bungard (2018), the validity of the construct is not very important. It has to do with the extent to which the measurement meets theoretical expectations. In our case, the research instrument has no theoretical validity.

Using correlation analysis, a reliability analysis of the research instrument was conducted. The Cronbach alpha of all generalised factors is greater than 0.6 (see Table 2), viz. the internal reliability of the test is sufficient and good to allow such a scale to be used in statistical analysis.

Table 2: Research instrument Cronbach alpha

\begin{tabular}{|l|c|c|c|}
\hline & $\begin{array}{l}\text { The current approach to the } \\
\text { characteristics of the } \\
\text { profession }\end{array}$ & $\begin{array}{l}\text { Previous approach to the } \\
\text { characteristics of the } \\
\text { profession (before choosing } \\
\text { a profession) }\end{array}$ & $\begin{array}{l}\text { Evaluation of professional } \\
\text { traits as like / dislike }\end{array}$ \\
\hline $\begin{array}{l}\text { Questionnaire } \\
\text { question groups }\end{array}$ & A.1-A.24 & B.1-B.24 & C.1-C.24 \\
\hline Cronbach alpha & 0,695 & 0,787 & 0,824 \\
\hline
\end{tabular}

\section{RESEARCH RESULTS}

After testing the hypothesis: the average of the respondents' assessment of the current attitude towards the characteristics of the police officer profession differs statistically significantly from the attitude before choosing this profession; the result described below was obtained. 
INDEPENDENT JOURNAL OF MANAGEMENT \& PRODUCTION (IJM\&P)

http://www.ijmp.jor.br

v. 12, n. 6, Special Edition ISE, S\&P - November 2021

ISSN: 2236-269X

DOI: 10.14807/ijmp.v12i6.1756

Applying the paired Student-t test, we see that $\mathrm{p}=0.000<\alpha$ (see Table 4). In our case, the average difference in the respondents' assessment of the current attitude towards the characteristics of the police officer profession is lower than the difference in the attitude before choosing this profession, viz. $60.5690<62.8793$ (see Table 3).

Table 3: Paired student-t test analysis and descriptive statistics

\begin{tabular}{|c|c|c|c|c|}
\hline & Average difference & Number of cases & Standard deviation & Standard error \\
\hline The current approach & 60,5690 & 375 & 5,41532 &, 50280 \\
The previous approach & 62,8793 & 375 & 7,16532 &, 66528 \\
\hline
\end{tabular}

Table 4: Paired student-t test analysis results

\begin{tabular}{|c|c|c|c|}
\hline & Number of cases & Correlation & Criterion $p$ value \\
\hline The current \& previous approach & 375 & 0,482 & 0,000 \\
\hline
\end{tabular}

The hypothesis that the average assessment of the respondents' current attitude towards the characteristics of the police officer profession differs statistically significantly from the attitude before choosing this profession was confirmed. It turned out that the average assessment of the respondents' current attitude towards the characteristics of the police officer profession is statistically significantly lower than the attitude before choosing this profession.

A two-factor analysis of variance was used to support the hypothesis that the assessment of occupational characteristics was statistically significantly dependent on an officer's length of service, age, and current police rank. The variances in the populations did not differ statistically significantly $(p=0.092)$. Analyzing the examination of the effects of factors, it can be seen that the statistically significant averages of the assessment of occupational characteristics are in the groups of respondents with different police ranks $(\mathrm{p}=$ $0.000)$, and in the gender groups the differences in the averages are not significant ( $\mathrm{p}=$ 0.602). There is also no statistically significant relationship between gender and police rank $(\mathrm{p}=0,877)$.

The Scheffe criterion shows that there is a statistically significant difference between those without a rank and those with an inspector's rank $(\mathrm{p}=0.02)$ and those without a rank and a senior inspector or with an even higher rank $(\mathrm{p}=0.01)$. Examining the magnitude of the difference between the group means, we see that having an inspector's, chief inspector's or an even higher rank is statistically significantly less likely to like the characteristics of his profession than future officials who do not yet have a rank. 
The results of the questionnaire show the average assessment of the characteristics of the profession depending on the gender of the respondents and their police rank. It can be observed that the average assessment of the occupational characteristics of both men and women decreases depending on their police rank.

\section{CONCLUSIONS AND RECOMMENDATIONS}

Aspects of choosing a profession and career planning are closely related to the description of the characteristics of the image of the profession, otherwise known as the image of the profession. Therefore, if the feeling of vocation is present, it is very important that the choice of profession is as precise as possible. If job satisfaction is felt and job expectations coincide with the current situation, then a successful individually pursued career is developing. In order to develop a successful or fulfilling career, it is necessary to carefully systematize the characteristics of a particular profession, this will help you decide whether to choose that specific profession or not.

After an empirical study, the first hypothesis - the average of the respondents' assessment of the current attitude towards the characteristics of the police officer profession is statistically significantly different from the attitude before choosing this profession - was confirmed.

The second hypothesis was partially confirmed. It was revealed that the average assessment of the characteristics of the police profession for both men and women decreases depending on their police rank. An inspector's, chief inspector's or even higher ranks statistically significantly less value the police profession's characteristics as likeable than student officers who do not yet have a rank.

This shows that when choosing a profession, it is important to have lists of characteristics of the profession prepared in advance, which would help young people to choose a profession as precisely and clearly as possible, so that there would be no such differences in attitudes later on. Programs should also be developed to improve the knowledge about professions before they are chosen.

\section{REFERENCES}

Augiene, D. (2918). Career specialist activity importance in the constantly changing activity world context. Baltic Journal of Career Education and Management, 6(1), 2018. DOI: 10.33225/bjcem/18.6.4.

Benesch, H. (2002). Atlas of Psychology, t. II. Vilnius: Alma litera. 
INDEPENDENT JOURNAL OF MANAGEMENT \& PRODUCTION (IJM\&P)

http://www.ijmp.jor.br

v. 12, n. 6, Special Edition ISE, S\&P - November 2021

ISSN: 2236-269X

DOI: 10.14807/ijmp.v12i6.1756

Beresneviciene, D. (2003). Young adult psychology. Vilnius: Presvika.

Braendle, T., \& Grundmann, M. (2020). Social determinants of study and career choices. Career Orientation: A Textbook and Workbook.

Bungard, W. (2018). Employee surveys. In Feedback instruments in the company, 173190. Springer Gabler, Wiesbaden.

Crime and law enforcement activities. Statistics Lithuania, Vilnius. Retrivied from https://osp.stat.gov.lt/statistiniu-rodikliu-analize?hash=9071d89b-57ce-4040-8efc3cf92c758579\#/. Access: 12 August 2021

Greenhaus, J. H., \& Callanan, G. A. (Eds.) (2006). Encyclopedia of career development. Sage Publications. DOI: http://dx.doi.org/10.4135/9781412952675.

Gottfredson, S. L. (1981). Circumscription and compromise: A developmental theory of occupational aspirations. Journal of Counseling psychology, 28(6), 545-579. DOI: 10.1037/0022-0167.28.6.545.

Grecco, A. B. B., Velázquez, D. R. T., \& Mastrapa, L. H. (2021). Managerial Styles and their Relationship with Job Satisfaction in Information Technology Companies. Independent Journal of Management \& Production, 12(4), 1123-1138. DOI: http://dx.doi.org/10.14807/ijmp.v12i4.1363

Jovaisa, L. (2001). Educational science and practice. Vilnius: Agora.

Kardelis, K. (2016). Mokslinių tyrimų metodologija ir metodai [Methodology and Methods of Scientific Research]. Vilnius: Mokslo enciklopedijų leidybos centras.

Kirkpatrick, J. M., \& Mortimer, J. T. (2002). Career choice and development from sociological perspective. Career choice and development, 4th Edition.

Lauzackas, R. (2005). Vocational training methodology. Kaunas.

Le-Hoang, P. V., Ho, V. T., \& Phan, N. T. (2020). Factors Affecting Employee Satisfaction: the Case of Land Plot Sales Staffs. Independent Journal of Management \& Production, 11(1), 180-193. DOI: 10.14807/ijmp.v11i1.1025.

McMahon, M., \& Patton, W. (2018). Systemic thinking in career development theory: Contributions of the systems theory framework. British Journal of Guidance \& Counselling, 46(2), 229-40. DOI: 10.1080/03069885.2018.1428941

Mitchell, L. K., \& Krumboltz, J. D. (1990). Social Learning Approach to Career Decision Making: Krumboltz's Theory, Career Choise and Development: Applying Contemprorary Theory to Practice.

Pukelis, K., \& Navickiene, L. (2008). Career designing: new concept overcoming intercultural and linguistic barriers. Pedagogika, 90, 12-17.

Pukelis, K. (2007). Career design methodology. Kaunas: VDU.

Rupsiene, L., \& Rutkiene, A. (2015). Educational experiment. Klaipėda: KU.

Sakalas, A., \& Silingienė, V. (2000). Personnel Management. Kaunas: Technologija.

Sakalas, A., \& Salcius, A. (1997). Career management. Kaunas: Technologija.

Samad, A., Memon, S. B., \& Ali, I. (2021). Despotic Leadership and Job Satisfaction among Nurses: Role of Emotional Exhaustion. Independent Journal of Management \& Production, 12(1), 127-142. DOI: https://doi.org/10.14807/ijmp.v12i1.1344. 
Schaufeli, W., Salanova, M., González-Romá, V., \& Bakker, A. (2002). The measurement of engagement and burnout: a two-sample confirmatory factor analytic approach. Happiness Stud., 3, 71-92. DOI: 10.1023/A:1015630930326.

Scheer, C. A. (2010). Do the police keep what the police said they would do? Frankfurt: Police Science Publishing House.

Super, D. E. (1990). A life-span, life-space approach to career development. Career choice and development: applying contemporary theories to practice, pp. 197-261. DOI: 10.1016/0001-879(80)90056-1.

Swanson, J. L., \& Schneider, M. (2020). The Theory of Work Adjustment. Career development and counselling: Putting theory and research to work.

Wadhwa P., \& Guthrie, J. (2018). Strategic human resources management and organizational effectiveness in hospitality settings. American Journal of Management, 18(1), 10-24. 